\title{
The effect of dietary amino acid composition on protein and energy balance in growing pigs ${ }^{*}$
}

\author{
H. Fandrejewski, D. Weremko, St. Raj and G. Skiba
}

The Kielanowski Institute of Animal Physiology and Nutrition,

Polish Academy of Sciences

05-Ilo Jablonna, Poland

\begin{abstract}
Protein and energy deposition in the body were measured in 20 pigs from 25 to $70 \mathrm{~kg}$ body weight, which were fed isoprotein and isoenergetic diets adequate (A) in ileal digestible amino acid content, deficient in lysinc by $20 \%$ (D) or $40 \%$ (VD), or containing lysine and methionine in $20 \%$ excess (E). Protein deposition in VD and D pigs was respectively 26 and $9 \%$ lower, whereas in the $\mathrm{E}$ pigs it was similar to that in A pigs. Utilization of digestible lysine was inversely $(\mathrm{r}=-0.52)$ related to the amount of protein deposited in the body. Dietary supplementation with amino acids had no effect on utilization of metabolizable energy (on average 33\%). However, heat production related to maintenance and protein deposition was reduced by $0.38 \mathrm{~kJ} / \mathrm{kg}^{0.75}(\mathrm{P}=0.07)$ per $\mathrm{kJ}$ energy additionally retained as protein.
\end{abstract}

KEY WORDS: growing pigs, ileal digestible amino acids, protein balance, energy balance

\section{INTRODUCTION}

Protein gain in the body is the outcome of the competing processes of protein synthesis and protein degradation (turnover). These processes change in similar or opposite directions depending on animal and dietary factors (Simon, 1989). Theoretically, any changes in the rate of protein turnover affect energy metabolism because both protein synthesis and protein degradation are energy-consuming processes (Reeds and Mersmann, 1991).

\footnotetext{
* Supported by the State Committee for Scientific Research, Grant No. 5 P06E 03212
} 
It has been shown that turnover of protein in pigs changed when they were fed diets imbalanced by supplementation with amino acids (Salter et al., 1990; Saggau et al., 2000). However, short-term experiments on energy metabolism with pigs fed semi-synthetic diets varied in the biological value of protein (Fuller et al., 1987; Beyer et al., 2000) showed no significant relationship between protein and energy metabolism.

The aim of this work was to study the long-term influence of dietary amino acid composition when feeds were based on ingredients commonly used in pig nutrition. Diets were formulated according to ileal digestibility (apparent) of amino acids.

\section{MATERIAL AND METHODS}

Growing pigs of a synthetic line randomly allotted into four treatment groups (4 gilts from each of 5 litters) and from 25 to $70 \mathrm{~kg}$ body weight (BW) were fed a basal diet (group VD) or a basal diet partially or adequately supplemented with synthetic amino acids (groups D, A and E). The basal diet was composed of $(\mathrm{g} / \mathrm{kg}$ ): wheat, 696; rapeseed oilmeal, 220; maize starch, 60; and vitamin-mineral premix, 24. In $1 \mathrm{~kg}$ DM it contained about, g: crude protein, 193; ether extract, 17; ash 49, and gross energy, $18.8 \mathrm{MJ}$. The content and proportion of individual AA in the basal diet (diet VD; Table 1) were determined in a preliminary ileal experiment with surgically modified pigs (Buraczewska et al., 1999), but they were still below current recommendations (CVB, 1995). Diet D was supplemented with $0.21 \%$ L-lysine $\mathrm{HCl}$, but it was still deficient in comparison with AA pattern (Table 1). Diet A (adequate) was supplemented with $0.42 \%$ L-lysine $\mathrm{HCl}$ and $0.018 \%$ L-threonine and $0.015 \%$ L-tryptophan according to the AA standard. Diet E was

TABLE 1

Content of ileal digestible lysine, methionine, treonine and tryptophan in diets for pigs

\begin{tabular}{lcccc}
\hline & \multicolumn{4}{c}{ Diets with amino acids contents, \% } \\
\cline { 2 - 5 } Amino acid & $\begin{array}{c}\text { VD } \\
\text { very deficient }\end{array}$ & $\begin{array}{c}\mathrm{D} \\
\text { deficient }\end{array}$ & $\begin{array}{c}\mathrm{A} \\
\text { adequate }\end{array}$ & $\begin{array}{c}\mathrm{E} \\
\text { In excess }\end{array}$ \\
\hline Lysine & 0.44 & $0.60(0.16)$ & $0.75(0.31)$ & $0.91(0.47)$ \\
Methionine & 0.24 & 0.24 & 0.24 & $0.29(0.05)$ \\
Treonine & 0.41 & 0.41 & $0.43(0.018)$ & 0.41 \\
Tryptophan & 0.12 & 0.12 & $0.14(0.015)$ & 0.12 \\
Lys, g/MJ & 0.35 & 0.47 & 0.59 & 0.71 \\
Lys:Met:Thr:Trp & $100: 55: 95: 28$ & $100: 40: 69: 20$ & $100: 32: 57: 18^{*}$ & $100: 32: 45: 13$ \\
\hline
\end{tabular}

in brackets is shown amount of amino acid of crystalic origin

* standard (CVB, 1995) 
supplemented with $0.63 \% \mathrm{~L}$-lysine $\mathrm{HCl}$ and $0.053 \%$ DL-methionine to maintain the mutual proportion of AA (100:32), but the concentration of these AA was in excess of requirements. The pigs were fed twice daily according to a scale adjusted to their metabolic body weight $\left(120 \mathrm{~g} / \mathrm{kg}^{0.75}\right)$. They were kept in $2.6 \mathrm{~m}^{2}$ separate pens in a thermoneutral environment.

The pigs were slaughtered at $70 \mathrm{~kg}$ body weight after 16-h fasting and then their carcass, hair and offal were analyzed for chemical composition. Additionally, 5 pigs were slaughtered at $25 \mathrm{~kg}$ body weight to provide information on initial body composition. The composition of feed, faeces, and body was analyzed according to AOAC procedures (1994). Gross energy in feeds was determined by bomb calorimetry. Digestibility of energy (faecal) was determined during a threeday collection in all pigs in the middle of the study at approximately $45 \mathrm{~kg}$ body weight. Metabolizable energy (ME) was estimated as DE x 0.965 . Energy content in the body was estimated from the protein and fat content using the factors 23.86 and $39.76 \mathrm{~kJ} / \mathrm{g}$, respectively. Corrected heat production (HP') was calculated as ME - (1.4 fat gain+1.15 protein gain), where 1.4 is the equivalent of ME needed for fat deposition in growing gilts (Fandrejewski, 1992) and 1.15 is the equivalent of protein synthesis in vitro (Reeds and Mersmann, 1991).

Statistical analyses were performed using SAS procedures (1997). In analysis of variance two factors, dietary treatments and litter, were taken into account. Differences between groups were tested at $\mathrm{P}<0.05$.

\section{RESULTS}

Average daily gains and feed conversion rate increased as the diets' lysine content rose from 4.4 (group VD) to $7.5 \mathrm{~g} / \mathrm{kg}$ (group A; Table 2). Further increasing lysine to $9.1 \mathrm{~g} / \mathrm{kg}$ (group E) did not change growth performance parameters.

Pigs from Lys-deficient groups deposited daily 37 (VD) or $26 \%$ (D) less protein than the remaining pigs (Table 3). Groups $A$ and $E$ did not differ in respect to

TABLE 2

Growth performance of pigs fed from 25 to $70 \mathrm{~kg}$ diets of adequate (A) in ileal digestible amino acids content or deficit in lysine by $20 \%$ (D) or $40 \%$ (VD) or containing lysine and methionine in $20 \%$ excess (E)

\begin{tabular}{lccccr}
\hline & VD & D & A & E & SEM \\
\hline Feed intake, kg/day & 2.11 & 2.11 & 2.11 & 2.09 & 0.07 \\
Daily gain, g & $673^{\mathrm{a}}$ & $778^{\mathrm{b}}$ & $808^{\mathrm{b}}$ & $808^{\mathrm{b}}$ & 7.07 \\
Feed conversion ratio & $3.14^{\mathrm{a}}$ & $2.71^{\mathrm{b}}$ & $2.61^{\mathrm{b}}$ & $2.58^{\mathrm{b}}$ & 0.03 \\
\hline
\end{tabular}

a.b $-\mathrm{P}<0.05$ 
TABLE 3

Protein balance ( $\mathrm{g}$ per $\mathrm{kg}^{0.75}$ ) of pigs given diets of adequate (A) in ileal digestible amino acids content or deficit in lysine by $20 \%$ (D) or $40 \%$ (VD) or containing lysine and methionine in $20 \%$ excess (E)

\begin{tabular}{lccccc}
\hline & VD & D & A & E & SEM \\
\hline Lysine (ileal digestible) intake & $0.51^{\mathrm{a}}$ & $0.70^{\mathrm{b}}$ & $0.88^{\mathrm{c}}$ & $1.06^{\mathrm{d}}$ & 0.004 \\
Protein deposition & $5.48^{\mathrm{a}}$ & $6.79^{\mathrm{b}}$ & $7.44^{\mathrm{b}}$ & $7.34^{\mathrm{b}}$ & 0.110 \\
Crude protein utilization $^{\mathrm{b}}$ & $0.28^{\mathrm{a}}$ & $0.34^{\mathrm{b}}$ & $0.38^{\mathrm{b}}$ & $0.38^{\mathrm{b}}$ & 0.006 \\
Lysine utilization ' $^{\text {L }}$ & $0.78^{\mathrm{a}}$ & $0.71^{\mathrm{ab}}$ & $0.62^{\mathrm{b}}$ & $0.51^{\mathrm{c}}$ & 0.091 \\
\hline
\end{tabular}

1 assuming lysine content in the body gain as $7.3 \mathrm{~g} / 16 \mathrm{gN}$ (Wasilewko et al., 1996)

$\mathrm{a}, \mathrm{b}-\mathrm{P}<0.05$

the amount of protein deposited in the body of pigs. Utilization of lysine linearly decreased as protein deposition increased $(r=-0.52)$.

The energy balance (Table 4) showed that pigs from treatment VD deposited less energy in protein form than pigs fed diets supplemented with AA. Retention of energy as fat was highest $(\mathrm{P}>0.05)$ in the pigs fed the unsupplemented basal diet (VD). However, gross utilization of energy (RE/ME) was almost the same in all groups (32.4-33.4\%).

The value of $R E_{\text {prot }} / \mathrm{RE}_{\text {fat }}$ depended more on the rate of protein deposition ( $\left.t=26.7\right)$ than that of fat $(t=7.9)$. The HP' was somewhat higher in pigs fed the basal diet $\left(857 \mathrm{~kJ} / \mathrm{kg}^{0.75}\right)$ than those fed diets supplemented with synthetic amino acids, which was a loss of $836-843 \mathrm{~kJ}$ energy $/ \mathrm{kg}^{0.75}$. However, HP', relating to the amount of energy deposited in protein, decreased $(\mathrm{P}<0.01)$ with increasing protein deposition in the body.

TABLE 4

Energy metabolism, $\mathrm{kJ} / \mathrm{kg}^{0.75}$ of pigs given diets of adequate (A) in ileal digestible amino acids content or deficit in lysine by $20 \%$ (D) or $40 \%$ (VD) or containing lysine and methionine in $20 \%$ excess (E)

\begin{tabular}{lccccc}
\hline & VD & D & A & E & SEM \\
\hline Metabolizable energy & 1499 & 1494 & 1484 & 1469 & 4.58 \\
Retained energy as protein $\left(\mathrm{RE}_{\text {prot }}\right)$ & $131^{\mathrm{a}}$ & $162^{\mathrm{b}}$ & $176^{\mathrm{b}}$ & $175^{\mathrm{b}}$ & 2.83 \\
Retained energy as fat" $\left(\mathrm{RE}_{\text {fat }}\right)$ & 354 & 337 & 315 & 312 & 5.85 \\
$\mathrm{RE}_{\text {prot }} / \mathrm{RE}_{\text {fat }}$ & $2.71^{\mathrm{a}}$ & $2.09^{\mathrm{b}}$ & $1.81^{\mathrm{b}}$ & $1.81^{\mathrm{b}}$ & 0.06 \\
Retained energy/metabolizable energy & 0.324 & 0.334 & 0.331 & 0.331 & 3.08 \\
Heat production & 1014 & 995 & 993 & 982 & 7.00 \\
Heat production corrected' (HP') & 857 & 841 & 843 & 836 & 7.89 \\
HP'/ $^{\prime}$ & $6.54^{\mathrm{a}}$ & $5.19^{\mathrm{b}}$ & $4.79^{\mathrm{b}}$ & $4.81^{\mathrm{b}}$ & 0.103 \\
\hline
\end{tabular}

" effect of dam $(\mathrm{P}<0.05)$

a.b $-\mathrm{P}<0.05$ 


\section{DISCUSSION}

The diets used in this study were based on wheat and rapeseed meal, which are lysine-deficient ingredients. Particularly the latter is an example of feedstuffs with imbalanced lysine to sulphur amino acids. Therefore, supplementation of a basal diet with AA increased the rate of protein deposition and confirmed that lysine is the first limiting AA in cereal-rapeseed meal diets. In contrast, additionally supplying Lys and Met without simultaneously supplementing indispensable AA did not further increase the protein deposition rate, which emphasizes the importance of the ,ideal" protein principle in pig feeding.

In the present study, improving the biological value of protein in the diet resulted in increasing protein deposition and decreasing fat deposition. However, gross utilization of energy remained unchanged, which is in agreement with studies on pigs fed semi-synthetic diets (Fuller et al., 1987; Beyer et al., 2000). Nonetheless, the lack of differences in gross energy utilization is in opposition to the fact that the efficiency of energy utilization for protein retention is markedly lower than for fat retention (ARC, 1981), especially when energy retention is measured by the comparative slaughter technique (Fandrejewski, 1992). In growing animals, the energy costs of maintenance and of protein deposition should be considered jointly rather than separately (Kielanowski, 1976). This is because deposition of protein involves an overall increase of energy metabolism, which is probably partly due to an increase in protein turnover (Fuller et al., 1987). In the study of Fandrejewski (1992), increasing protein deposition through dietary rations increased HP' by $2.9 \mathrm{~kJ}$ per kJ of energy retained in protein form. In the present work, a regression coefficient of HP' on the rate of energy deposited in protein $\mathrm{ER}_{\text {prot }}$ (both in $\mathrm{kJ}$ per $\left.\mathrm{kg}^{0.75}\right)$ was reduced by $0.38 \pm 0.11 \mathrm{~kJ} / \mathrm{kJ}^{0.75}(\mathrm{P}=0.07)$ per $\mathrm{kJ}$ energy additionally retained as protein. This suggests that altering the quantity or quality of protein in pig nutrition changes energy metabolism related to protein anabolism in opposite directions, and at different rates.

\section{CONCLUSIONS}

Improving the amino acid composition of diets increased the protein deposition rate and protein/fat ratio in the body. It also reduced dissipation of energy as heat, however, the amount of energy saved in this way was not large. It seems that an excess of synthetic amino acids in diets for growing pigs does not significantly change their protein and energy metabolism. 


\section{REFERENCES}

AOAC, 1994. Association of Official Analytical Chemists. Official Methods of Analysis. 15 Edition. Washington, DC

ARC, 1981. The Nutrient Requirements of Pigs. Commonwealth Agricultural Bureau, Slough (UK)

Beyer M., Saggau E., Demo W., Jentsch W., Scholze H., Junghans P., Kuhla S., Klein M., Hagemeister H., 2000. Energy and protein metabolism of growing pigs fed on diets with casein or soy protein isolate as sole protcin source. In: A. Chwalibog, K. Jakobsen (Editors). Energy Metabolism in Animais. EAAP Publication No. 103, pp. 357-361

Buraczewska L., Wasilewko J., Fandrejewski H., Żebrowska T., Han K. In, 1999. Formulation of pig diets according to ileal digestible amino acids content. Livest. Prod. Sci. 59, 13-24

CVB, 1995. Central Leevoederbureau, No.18. Lelystad (The Netherlands)

Fandrejewski H., 1992. Energetic aspects of feed efficiency in growing pigs (in Polish). Thesis. The Kielanowski Institute of Animal Physiology and Nutrition (Editor). Jablonna (Poland), pp. 58

Fuller M.F., Cadenhead A., Mollisson G., Seve B., 1987. Effects of the amount and quality of dietary protein on nitrogen metabolism and heat production in growing pigs. Brit. J. Nutr. 58, 277-286

Kielanowski J., 1976. Energy cost of protein deposition. In: K.N. Boorman, P.J. Buttery, D. Luis, R.N. Neale, H. Swan, Dl.A. Cole (Editors). Protein Metabolism and Nutrition. Butterwords, London, Boston, pp. 207-215

Reeds Pl., Mersmann Hl., 1991. Protein and energy requirements of animal treated with B-adrenergic agonists: A discussion. J. Anim. Sci. 69, 1532-1550

Saggau E., Schadereit R., Beyer W., Sussenbeth A., Voigt J., Hagemeister H., 2000 Effects of dietary protein quality on protein tumover in growing pigs. J. Anim. Physiol. Anim. Nutr. 84, $29-42$

Salter D.N., Montgomerry A.I., Hudson A., Quclch D.B., Elliott RI., 1990. Lysine requirements and whole-body protein tumover in growing pigs. Brit. J. Nutr. 63, 505-513

Simon O., 1989. Metabolism of proteins and amino acids. In: H.D. Bock, B.O. Eggum, A.G. Low, O. Simon, T. Żebrowska (Editors). Protein Metabolism in Farm Animals. Evaluation, Digestion, Absorption and Metabolism. Oxford Science Publ., VEB Deut. Landw., Oxford, Berlin, pp. 273-366

Wasilewko J., Buraczewska L., Fandrejewski H., Raj S., 1999. Amino acid composition of protein deposited by pigs of Pietrain breed and 990 line fed ad libitum (in Polish). Proceedings of Conference on Nutrients Requirements of High Productivity Farm Animals. Krynica (Poland), pp. 263-267 


\section{STRESZCZENIE}

\section{Wplyw składu aminokwasowego diety na bilans bialka i energii u rosnących świń}

Bilans białka i energii określono metodą ubojową na 20 rosnących świniach, od 25 do $70 \mathrm{~kg}$, żywionych izobiałkową i izokaloryczną paszą zawierającą aminokwasy strawne (w jelicie cienkim) w ilości zgodnej z normami (A), lub obniżoną zawartością lizyny o 20 (D) i 40\% (VD), bądź zawierającą lizynę i metioninę w $20 \%$ nadmiarze. Stwierdzono, że odłożenie białka u świń żywionych paszą niedoborową pod względem lizyny było o 9-26\% niższe niż w grupie kontrolnej. Wykorzystanie lizyny strawnej pogarszało się wraz ze zwiększaniem poziomu odkładanego białka w ciele $(r=-0,52)$. Wykorzystanie pobranej energii metabolicznej na jej odłożenie w ciele wynosiło średnio $33 \%$ i nie zależało od czynnika doświadczalnego, natomiast straty energii w formie ciepła powstającego w wyniku potrzeb bytowych i odłożenia białka zmniejszały się o $0.38 \mathrm{~kJ}(\mathrm{P}=0,07)$ wraz ze zwiększaniem się retencji energii w białku o $1 \mathrm{~kJ} / \mathrm{kg}^{0.75} \mathrm{Nadmiar}$ lizyny i metioniny spowodowany dodatkiem aminokwasów syntetycznych nie zróżnicował wyników bilansu białka i energii. 